\title{
WIZJA MĘCZEŃSTWA W ZEZNANIACH MARIANNY POPIEŁUSZKO W PROCESIE BEATYFIKACYJNYM KS. JERZEGO POPIEŁUSZKI
}

„Czczę go i kocham jako męczennika za sprawy Boże”- oznajmiła matka ks. Jerzego Popiełuszki w czasie przesłuchania przed Trybunałem Beatyfikacyjnym w 1997 r. W historii Kościoła to ewenement, że matka była przesłuchiwana w procesie beatyfikacyjnym syna. Taka sytuacja wydarzyła się w przypadku Marianny Popiełuszko, która przed Trybunałem Beatyfikacyjnym w Warszawie odpowiadała na wszystkie pytania potrzebne do oceny życia i działalności kandydata na ołtarze przez kościelne komisje. Z tych zeznań wyłania się wyraźnie jej wizja życia i śmierci ks. Popiełuszki, ale także jego męczeństwa. Analiza tych wypowiedzi pozwala zobaczyć, dlaczego uznawała go za męczennika, i jakie czynniki na to męczeństwo, w jej rozumieniu, się składają.

\section{Pierwszy etap procesu beatyfikacyjnego}

Proces beatyfikacyjny ks. Popiełuszki rozpoczął się trzynaście lat po jego śmierci, w lutym 1997 r. Prymas Polski, kard. Józef Glemp, powołał na terenie archidiecezji warszawskiej² Trybunał Beatyfikacyjny, którego członkowie mieli za zadanie przesłuchać świadków

1 M. P o p i e $\nmid$ u s z k o, Zeznania $w$ procesie beatyfikacyjnym ks. Jerzego Popiełuszki, w teczce: Zeznania świadków w procesie beatyfikacyjnym ks. Jerzego Popiełuszki 1/70 t. 1 (zeznania M. Popiełuszko jako sessio 7a, obejmują strony 96-116), zachowanej w archiwum Ośrodka Dokumentacji Życia i Działalności Księdza Jerzego Popiełuszki w Warszawie. Z tego archiwalnego dokumentu pochodzą wszystkie fragmenty zeznań Marianny Popiełuszko cytowane w niniejszym artykule.

2 Zgodnie z wymogami prawa kanonicznego, pierwszy etap procesu beatyfikacyjnego toczy się na terenie diecezji, w której żył i pracował kandydat na 
życia i działalności ks. Popiełuszki, i zebrać dowody, że ks. Jerzy jako kapłan poniósł śmierć męczeńską za wiarę. Jak wynika z relacji o. Gabriela Bartoszewskiego, promotora sprawiedliwości w procesie beatyfikacyjnym, najważniejsze znaczenie miały świadectwa męczeństwa potwierdzające wiarę ks. Jerzego, jego wytrwałość w czasie prześladowań i ufność wobec Boga. ${ }^{3}$ Trybunał zajmował się też zbieraniem dowodów, że prześladowcy działali z nienawiści do Boga i do Kościoła.

Należy dodać, że proces beatyfikacyjny rozpoczął się w 1997 r. jako skutek spontanicznego szerokiego kultu, jakim otaczano ks. Popiełuszkę i jego grób na warszawskim Żoliborzu. Świadczyły o tym liczne pielgrzymki do tego miejsca z Polski, jak też z zagranicy, nawiedzanie grobu przez najwyższych przedstawicieli religijnych i państwowych. Jedną z najbardziej znaczących pielgrzymek było przybycie 14 czerwca 1987 r. do grobu ks. Jerzego papieża Jana Pawła II. Zarazem przez długi czas po 1984 r. nie brakowało głosów, które podważały męczeński charakter tej śmierci. Wynikały one z niezrozumienia religijnej postawy ks. Popiełuszki lub z tendencyjnego powtarzania opinii o politycznym wymiarze jego działalności, jakie lansowano już za jego życia. ${ }^{4}$ Chociaż „głos ludu” wyraźnie uznawał ks. Popiełuszkę za męczennika, Kościół oficjalnie nie wypowiadał się na ten temat. Pierwszy uczynił to papież Jan Paweł II. W jednej z homilii w czasie pielgrzymki do Polski w 1991 r. wspominał męczenników trzech pierwszych stuleci i męczenników współczesnych „na wschód od nas i u nas” i wśród nich umieszczał ks. Jerzego. Mówił o nim, że złożył „ofiarę z życia, tak jak Chrystus”, że poniósł „męczeńską śmierć”. ${ }^{5}$ Niedługo później, w 1994 r., w liście do prymasa J. Glempa, w 10. rocznicę śmierci

ołtarze. Dopiero po zakończeniu etapu diecezjalnego rozpoczyna swą pracę nad przygotowaną dokumentacją watykańska Kongregacja do Spraw Świętych.

3 Relacja ustna o. Gabriela Bartoszewskiego, zbiory własne autorki artykułu (dalej: zb. wł.).

4 Szerzej zob. M. K i n d z i u k, Wizerunek medialny ks. Jerzego Popietuszki w polskiej prasie w latach 1980-1984, Wydawnictwo UKSW, Warszawa 2013.

5 Zob. t a ż, Świadek prawdy. Życie i śmierć ks. Jerzego Popiełuszki, Częstochowa 20102, s. 496-497 (homilia podczas mszy św. we Włocławku 7 VI 1991). 
kapłana, Jan Paweł II używał już wyraźnych określeń: „kapłan-męczennik”, „męczeńska śmierć”, „męczeństwo”, „nieustraszony obrońca prawdy, sprawiedliwości, wolności i godności człowieka". ${ }^{6}$ Te papieskie wypowiedzi, obok spontanicznego kultu ks. Popiełuszki, doprowadziły do tego, że w 1997 r. rozpoczął się proces na poziomie diecezjalnym.

$\mathrm{Na}$ tajnych sesjach przesłuchano w sumie pięćdziesięciu świadków, którzy ks. Jerzego znali osobiście, towarzyszyli mu w jego pracy, zwłaszcza w ostatnich latach życia.

\section{Zeznania matki}

Wśród zeznających znalazła się Marianna Popiełuszko, matka duchownego (mieszkała we wsi Okopy w woj. białostockim, na przesłuchania przybyła do Warszawy). Nie była ona wprawdzie świadkiem całej działalności duszpasterskiej i kapłańskiej ks. Jerzego, jednak jej zeznania odegrały jedną z kluczowych ról, pokazały bowiem, jakie wartości ukształtowały osobowość kandydata na ołtarze, jak dom rodzinny wpłynął na jego formację duchową oraz jak matka ks. Jerzego przyjęła jego śmierć i jak ją traktowała.

Znamienne, że kiedy opowiadała o swoim synu, o różnych zdarzeniach z jego życia, określała go zawsze w ten sam sposób: „ks. Jerzy”. Z pietyzmem, jak mówi się o świętych. Jedynie gdy przywołała okres dzieciństwa, używała określenia: „mój syn Jerzy”.

Przez kilka dni odpowiadała na pytania Trybunału Beatyfikacyjnego, notariusz zaś spisywał wszystkie odpowiedzi. Powstał w wyniku tego dokument, który zaczynał się od formuły łacińskiej (dalej był w języku polskim):

„In Dei Nomine, Amen. Anno Domini 1997 die 25 mense Aprili hora 10.00 coram infrascripto Delegato episcopale in praesenti causa Beatificationis seu Declartionis Martyrii super vita, martyrio et fama martyrii atque super miris in genere Servi Dei Georgii Popiełuszko, sacerdotis Archidioecesis Varsaviensis, pro tribunali sedente in aula

6 Tamże, s. 502. 
Domus paroecialis S. Stanislai Kostka, prasentibus Iustitiae Promotore legitime citato, meque Notario, comparuit Marianna Popiełuszko testis inductus et citatus, cui delatum fuit iuramentum iuxta formulam 2 a sessione relatam, quod ille statim praestitit et sese subscripsit ut infra..."

Zanim Marianna Popiełuszko zaczęła zeznawać, została pouczona o potrzebie mówienia prawdy i zachowania tajemnicy o tym, o co będzie pytana. ${ }^{8}$ Złożyła przysięgę na Biblię, że będzie mówić prawdę oraz że w swych wypowiedziach nie jest przez nikogo sterowana, tylko przekazuje swoje opinie: „Nie byłam pouczana, co i jak mam zeznawać. W składaniu zeznań kieruję się miłością do Pana Boga (...). O swoim synu pragnę zeznawać w oparciu o swoje wiadomości, ponieważ jestem jego matką".

Wyjaśniła także, dlaczego wyraziła zgodę na te zeznania. Jak podkreślała, pragnie beatyfikacji swojego syna, a jest to konsekwencją jej wcześniejszych wyborów, jakimi kierowała się wobec syna: „Modliłam się kiedyś, a było to w czasie ciąży, o łaskę powołania dla swego dziecka. Powiedziałam wtedy Panu Bogu, że jak będzie syn, żeby został kapłanem, a jeśli dziewczynka - zakonnicą. Ofiarowałam go jeszcze przed urodzeniem Panu Bogu i na jego śmierć patrzę w konsekwencji jako na swoją ofiarę. W życiu starałam się wszystkie doznane cierpienia ofiarowywać w intencji swoich dzieci”.

Marianna Popiełuszko odpowiadała kolejno na wszystkie pytania, które zostały zestawione w bloki tematyczne i podzielone na części obejmujące poszczególne okresy życia ks. Jerzego. ${ }^{9}$ Członków

7 Poza wstępem łacińskim, cały tekst przesłuchań jest zredagowany w języku polskim. Zaczyna się od powtórzenia informacji zawartej w nagłówku łacińskim: „W święto Św. Marka Ewangelisty 25.04.1997 r. stawiła się w siedzibie Trybunału Beatyfikacyjnego Marianna Popiełuszko - matka Sługi Bożego Jerzego Popiełuszki, w celu złożenia zeznań”; M. P o p i e ł u s z k o, Zeznania w procesie beatyfikacyjnym ks. Jerzego Popietuszki, s. 96.

8 Wszystkich zeznających obowiązywała tajemnica do momentu beatyfikacji ks. Popiełuszki. Po wyniesieniu go na ołtarze dokumenty te zostały odtajnione.

9 Dokument składa się z następujących części: Pytania dotyczące osoby świadka; Życie i działalność Sługi Bożego (dzieciństwo i młodość; szkoła średnia 
Trybunału interesowało zarówno dzieciństwo, młodość, jak i też późniejsze lata jego życia.

\section{Taki byl od dzieciństwa}

W zeznaniach odpowiadała na pytania dotyczące religijności swego syna poczynając od szkolnego okresu jego życia: „Do pierwszej spowiedzi świętej i I Komunii przygotowywał się w kościele parafialnym [w Suchowoli], bo wtedy nie było religii w szkole. Jerzy musiał być jednym ze zdolniejszych w grupie, ponieważ zdarzało się, że zastępował siostrę zakonną w nauczaniu kolegów i koleżanek katechizmu. Po I Komunii św. został ministrantem i był nim aż do wstąpienia do seminarium. Jako ministrant wyróżniał się w gorliwości. Mimo $5 \mathrm{~km}$ do kościoła zajął pierwsze miejsce za ilość wysłuchanych Mszy św. Dostał wtedy nagrodę: łyżwy i śpiewnik z pieśniami kościelnymi”.

Od dziecka dostrzegała u niego predyspozycje do kapłaństwa: „Mój syn Jerzy okazywał znaki powołania od maleńka. Do momentu otrzymania matury nikomu nie mówił o chęci wstąpienia do seminarium. Było to podyktowane obawami. Młodzieńcy, którzy wyrazili ochotę pójścia do seminarium, byli szykanowani przez Służbę Bezpieczeństwa. Jerzy również w klasie maturalnej miał propozycję pójścia na studia do Moskwy. Bezpieczniej więc było przed otrzymaniem świadectwa maturalnego nic nie mówić o swoich zamiarach".

Jak podkreślała, już w wieku szkolnym przejawiał zamiłowanie do kapłaństwa: „Stół w domu przebudowywał na ołtarz. Ustawiał na nim swoje obrazki, a nawet usiłował skonstruować kadzielnicę.

\footnotetext{
i seminarium; święcenia i praca kapłańska; praca duszpasterska przy kościele św. Stanisława Kostki; prześladowanie i męczeństwo); Cnoty Sługi Bożego (cnoty teologalne; cnoty kardynalne; cnoty moralne); Dary nadprzyrodzone; Zagadnienia związane z brakiem kultu; Sława męczeństwa; Łaski otrzymane za przyczyną Sługi Bożego; Pytania końcowe; por. Zeznania świadków w procesie beatyfikacyjnym ks. Jerzego Popiełuszki 1/70 t. 1 i 2, Ośrodek Dokumentacji Życia i Działalności Księdza Jerzego Popiełuszki w Warszawie.
} 
Chętnie uczestniczył w naszych domowych modlitwach. Zarówno on, jak i pozostałe nasze dzieci nie były do tego przymuszane".

Religijna atmosfera domu rodzinnego $\mathrm{w}$ jej przekonaniu musiała wywrzeć znaczący wpływ na postawę syna w dorosłym życiu. Podobnie, jak jego młodzieńcza gorliwość.

Z zeznań procesowych: „Do sakramentów świętych: spowiedzi i Komunii przystępował, ale nie mogę powiedzieć, jak było to często. W tamtych czasach nie było zachęty, żeby przystępować do Komunii św. codziennie i w niedzielę. Do Komunii św. przystępowaliśmy przez jakiś czas po odbytej spowiedzi. Nie przypominam sobie, kiedy zaczął obchodzić pierwsze piątki miesiąca. Było w nim jednak pragnienie kapłaństwa. W okresie młodzieńczym, gdy wyrósł z wieku dziecięcego, modlił się sam. Modlił się zawsze rano i wieczorem. Mieliśmy i mamy w domu taki zwyczaj, że klękamy do pacierza zaraz po przebudzeniu się, a potem przed spaniem. Jerzy robił to zawsze".

Należy stwierdzić, że z całą pewnością życie rodziny Popiełuszków koncentrowało się wokół wiary, która zresztą była dla nich czymś zupełnie naturalnym. Przeplatała się z codziennym życiem, wpisywała się w rytm dni, tygodni i lat, stanowiąc nierozdzielny element całości. „Bo przecież najważniejsze w życiu to dać dzieciom Boga”. ${ }^{10}$

Nawet domowe menu matka dostosowywała do rytmu religijnego i trzy razy w tygodniu - w środy, piątki i soboty - gotowała rodzinie postne posiłki, ucząc w ten sposób dzieci wyrzeczenia i postu. „Człowiek od dziecka musi wiedzieć, że w życiu potrzebne są wyrzeczenia, że nie wszystko jest tak, jak chcesz".

W oczach Marianny Popiełuszko, to Dekalog stanowił życiowy drogowskaz całej rodziny. Dlatego mówiła w zeznaniach: „Mój syn Jerzy własne i cudze rzeczy szanował, od maleńka był nauczony, że nie sięga się po cudze rzeczy - choćby jabłko leżące w cudzym ogrodzie".

\footnotetext{
10 Relacja ustna Marianny Popiełuszko, zb. wł.

11 Tamże.
} 


\section{Co wycierpiał w wojsku}

Zeznania procesowe pokazują również, że była dopytywana o postawę jej syna w czasie służby wojskowej, jaką odbywał on już jako alumn Wyższego Seminarium Duchownego, w jednostce specjalnej dla kleryków w Bartoszycach. ${ }^{12}$

Mówiła: „O tym wszystkim, co on przecierpiał w wojsku, dowiedziałam się od jego kolegów. On mi powiedział tylko o różańcu, który zabraniali mu nosić na palcu jego dowódcy. Powiedział mi, że nie posłuchał się dowódcy i różańca nie oddał”.

Syn nie żalił się jednak swym rodzicom z powodu wojskowych trudności: „O prześladowaniu Jerzego z powodu praktyk religijnych wiem tylko od jego kolegów. Mówili o tym, że stał długi czas na mrozie bez butów, goniono go po schodach w pełnym rynsztunku wojskowym i pozbawiano przepustek do rodziców i seminarium. Koledzy Jerzego wyznali mi, że był dla nich duchowym przywódcą i podtrzymywał ich w powołaniu do kapłaństwa".

Matka była jednak świadoma, że okres służby wojskowej ujawnił niezwykłą determinację jej syna w sprawach wiary i w gotowości do obrony wyznawanych wartości w ekstremalnych sytuacjach. W tym samym duchu mówił abp Angelo Amato podczas mszy beatyfikacyjnej ks. Popiełuszki w Warszawie, 6 czerwca 2010 r.: „,[służba wojskowa] była dla niego czasem wielkiego cierpienia, okresem licznych upokorzeń i ograniczenia wolności religijnej. Nie pozwalano mu uczestniczyć w Mszy św. i przyjmować komunii świętej”. ${ }^{3}$

12 Jerzy Popiełuszko odbywał służbę wojskową w jednostce specjalnej w Bartoszycach w latach 1966-1968. Kleryków powoływano wówczas do wojska w wyniku złamania porozumienia między rządem a Episkopatem z kwietnia 1950 r., które miało gwarantować odroczenie seminarzystom służby wojskowej. Głównym celem służby wojskowej alumnów był zamiar odciągnięcia ich od powołania kapłańskiego oraz ideologiczna indoktrynacja; zob. A. L e s i ń s k i, Stużba wojskowa kleryków w PRL 1959-1980, Olsztyn 2010.

13 A. A m a t o, Homilia. Beatyfikacja ks. Jerzego Popiełuszki 6 VI 2010, L'Osservatore Romano, wyd. pol. 7/2010, s. 58-60. 
Najważniejszym jednak przejawem wierności ks. Popiełuszki zasadom wiary w trudnych czasach komunistycznych była jego wytrwała działalność duszpasterska w ostatnich latach jego życia, w tym także sprawowane przez niego w kościele św. Stanisława Kostki w Warszawie Msze za Ojczyznę. ${ }^{14}$ Matka mówiła w zeznaniach: „Władze świeckie zaczęły z niechęcią odnosić się do Mszy św. za Ojczyznę, ponieważ dzięki niej wzmacniała się wiara ludzi w niej uczestniczących, a to nie było na rękę komunistom".

Broniła także religijnego charakteru tych liturgicznych zgromadzeń: „Mój syn, ksiądz Jerzy, nigdy nie czynił czegoś, co by podburzało ludzi do zakłócania porządku i bezpieczeństwa publicznego. Pod koniec Mszy św. zawsze prosił wiernych, żeby rozchodzili się w spokoju. Przestrzegał czasem przed prowokatorami”.

Jej zdaniem, ks. Jerzy wykazywał w swoim działaniu roztropność chrześcijańską: „Sądzę, że był roztropny nawet wtedy, kiedy podejmował się różnych zajęć duszpasterskich, za które był prześladowany. Roztropność to jest właściwy wybór między różnymi możliwościami. Jego obowiązki kapłańskie nakazywały mu podejmować się nawet takich czynności, za które był prześladowany. Nasza religia w Polsce za komunistów była jak mała szpilka w piasku i on tę szpilkę starał się odsłonić, zwłaszcza dla młodzieży. Chociaż syn zginął z ręki komunistycznych morderców, to jednak uważam, że to, co robił, było roztropne i potrzebne".

Powód prześladowań ks. Jerzego w ten sam sposób, co w swych zeznaniach uczyniła Marianna Popiełuszko, zinterpretował po latach abp Angelo Amato, tłumacząc powody prześladowania: „Religia, Ewangelia, godność osoby ludzkiej, wolność nie były pojęciami zgodnymi z ideologią marksistowską. To właśnie dlatego rozpętał się przeciw niemu [tj. ks. Jerzemu] niszczący gniew wielkiego kłamcy, nieprzyjaciela Boga i ciemiężcy ludzkości, tego, który nienawidzi

14 Mszę za Ojczyznę ks. J. Popiełuszko odprawiał od stycznia 1982 r. w kościele św. Stanisława Kostki w Warszawie, zawsze w ostatnią niedzielę miesiąca. Homilie, jakie wygłaszał, cieszyły się ogromną popularnością, dlatego te msze gromadziły tysiące ludzi z całej Polski. Szerzej zob. M. K i n d z i u k, Świadek prawdy. 
prawdy i szerzy kłamstwo. W tamtych latach, jak zdarzało się to niekiedy w historii, na dużym obszarze Europy, światło rozumu zostało przyćmione ciemnością, a dobro zastąpione złem (...). Za pomocą jedynie duchowych środków, takich jak prawda, sprawiedliwość oraz miłość, [ks. Popiełuszko] domagał się wolności sumienia obywatela i kapłana. Lecz zgubna ideologia nie znosiła światła prawdy i sprawiedliwości”."15

\section{Było w nim dużo ufności}

Do Marianny Popiełuszko docierały echa nie tylko z Mszy za Ojczyznę, wiedziała również o innych prześladowaniach, o negatywnej kampanii wobec ks. Jerzego, która nasiliła się od kwietnia 1982 r., odkąd ks. Popiełuszko znalazł się w ,aktywnym zainteresowaniu Wydz. IV KSMO (Komendy Stołecznej Milicji Obywatelskiej) w Warszawie w ramach tzw. TEOK"16 - teczki operacyjnej księdza. To ,aktywne zainteresowanie” IV Wydziału ks. Popiełuszką początkowo było tzw. działaniem operacyjnym Służby Bezpieczeństwa, a potem, od końca 1983 r. zyskało oprawę propagandową, której przewodził i którą kierował ówczesny rzecznik rządu PRL, Jerzy Urban. Ministerstwo Spraw Wewnętrznych też regularnie tworzyło pisemne raporty, zatytułowane Działania kleru katolickiego. ${ }^{17}$ Pojawił się w nich specjalny dział: Przebieg imprez z udziałem ks. J. Popiełuszki. ${ }^{18}$ Funkcjonariusze SB skrupulatnie gromadzili materiały

15 A. A m a t o, Homilia. Beatyfikacja ks. Jerzego Popiełuszki 6 VI 2010, s. 58-60.

16 TEOK - Karta Jerzego Popiełuszki z archiwów milicji, b. sygn.; Ośrodek Dokumentacji Życia i Działalności ks. Jerzego Popiełuszki w Warszawie.

${ }_{17}$ Chodzi tu o zbiory znajdujące się w Archiwum Akt Nowych. Są to dokumenty Urzędu Rady Ministrów zawierające materiały Biura Prasowego Rzecznika Rządu Jerzego Urbana z lat 1981-1988.

18 Raport Ministerstwa Spraw Wewnętrznych z 8 X 1984 r. wraz z Załacznikiem do punktu ,działania kleru katolickiego” dot. przebiegu imprez z udziałem ks. J. Popiełuszki w kościele Podwyższenia krzyża św. w Bytomiu w dniu 8.10.1984, bez sygn.; Ośrodek Dokumentacji Życia i Działalności ks. Jerzego Popiełuszki w Warszawie. 
dotyczące jego działalności, nagrywali jego homilie, przesłuchiwali różne osoby uczestniczące we wszystkich mszach przez niego odprawianych, samego ks. Jerzego też wzywano na przesłuchania. ${ }^{19}$

W zeznaniach tak o tym mówiła: „Syn, ksiądz Jerzy, był wzywany na różne przesłuchania do prokuratury, ale szczegółów nie pamiętam. Wiadomo mi, że po przesłuchaniach grożono synowi procesem (...) Jako matka mogę powiedzieć, że w księdzu Jerzym było dużo ufności. $\mathrm{W}$ różnych trudnościach i doświadczeniach polecał się Bogu i Jemu ufał. Swoją ufność wyrażał w modlitwie (...). Stwierdzam, że był człowiekiem pełnym zaufania Panu Bogu. Nie zauważyłam u niego żadnych aktów desperacji”.

Słowa te pokazują, że Marianna Popiełuszko postawę ufności Panu Bogu uznawała za bardzo istotną w reakcjach ks. Jerzego. Podobnie jak praktykę miłości bliźniego, na którą również zwróciła w swych zeznaniach uwagę: „Ksiądz Jerzy, mój syn, odznaczał się dużą życzliwością i miłością względem ludzi. Miał otwartą postawę na innych. Gdy był mały, dzielił się z rodzeństwem i kolegami nawet jednym orzechem, nie zatrzymywał dla siebie. Podobnie było w okresie jego młodości, a potem w latach jego życia kapłańskiego. Był otwarty na potrzeby potrzebujących. Przypominam sobie zdarzenie z synem Józefem, który odwiedził księdza Jerzego w Warszawie, akurat ksiądz Jerzy nagromadził sporo obuwia dla dzieci i syn Józef powiedział: «Mógłbyś dać mi jakieś buciki dla moich dzieci». On wtedy uśmiechnął się i powiedział, że tobie się źle nie powodzi, a ja mam dużo sierot $i$ te buciki przeznaczyłem dla nich. Wiadomo mi, że w stanie wojennym dużo pomagał ludziom biednym i uwięzionym, ale szczegółów nie znam, ponieważ mieszkam daleko od Warszawy".

Te elementy zeznań Marianny Popiełuszko były istotne także w procesie mającym potwierdzić męczeństwo ks. Jerzego. Zgodnie bowiem ze starożytną myślą Kościoła, męczeństwo nie dotyczy samego momentu śmierci, ale jest ukoronowaniem całego życia naznaczonego mocno wiarą i miłością. Także oficjalne kościelne

19 Por. Aparat represji wobec księdza Jerzego Popiełuszki 1982-1984, t. 1, wstęp J. Ż a r y n, Warszawa 2009. 
dokumenty o męczeństwie „za wiarę" nie zawężają pojęcia „wiara” jedynie do wyznawania prawd religijnych, ale obejmują nim także wartości i czyny, jakie z niej wypływają . ${ }^{20}$ Czyny miłości przede wszystkim.

\section{Widziałam go, gdy był w trumnie}

Aby zrozumieć treść zeznań Marianny Popiełuszko na temat samej śmierci jej syna, należy przypomnieć wydarzenia z 1984 r. i ówczesną jej reakcję na porwanie syna.

Gdy ks. Popiełuszko został uprowadzony 19 października 1984 r., Marianna Popiełuszko jeszcze nic o tym nie wiedziała. Dopiero następnego dnia w „Dzienniku Telewizyjnym” usłyszała, jak wszyscy inni widzowie, lakoniczny komunikat, odczytany za Polską Agencją Prasową: „19 bm. około godz. 22.00 w okolicach miejscowości Górsk koło Torunia został uprowadzony przez nieznanych sprawców ksiądz Jerzy Popiełuszko urodzony 14.09.1947 roku, zamieszkały w Warszawie. W związku z prowadzonym śledztwem prosi się osoby, które mogą udzielić jakichkolwiek informacji w tej sprawie, o niezwłoczne nawiązanie kontaktu lub powiadomienie najbliższej jednostki prokuratury lub Milicji Obywatelskiej. W szczególności prosi się wszystkich, którzy mogą udzielić informacji o osobach, których rysopisy podano wyżej i posługujących się samochodem Fiat 125p, o osobach, które bezprawnie wyrabiają lub posługują się tablicami rejestracyjnymi, oraz osobach, które bezprawnie posiadają lub używają umundurowanie milicyjne lub wyposażenie służbowe funkcjonariuszy MO, na przykład kajdanki". ${ }^{21}$

20 Por. H. M i s z t a 1, Sanctorum Mater: instrukcja Kongregacji Spraw Kanonizacyjnych o prowadzeniu dochodzenia diecezjalnego lub eparchialnego w sprawach kanonizacyjnych: komentarz, Lublin 20112.

${ }^{21}$ Informację za Polską Agencją Prasową, podległą rządowi, podała TVP 20 X 1984 r. w głównym wydaniu „Dziennika Telewizyjnego” o godz. 19.30. Następnego dnia, 21 X 1984, przedrukowały ją główne rządowe dzienniki: „Trybuna Ludu”, „Rzeczpospolita”, „Żołnierz Wolności”, „Życie Warszawy”. Por. Biuro Prasowe Rządu, Konferencja prasowa Jerzego Urbana 27 XI 1984. Stenogram, informacja, notatki. 1984, Sygn. 222/90. 
Pamiętała słowa, które usłyszała wówczas od swego męża, Władysława: „Żeby tylko jego kosteczki zobaczyć!”. Następnego dnia obydwoje udali się do Warszawy, gdzie przed kościołem św. Stanisława Kostki na Żoliborzu ujrzeli tłumy modlących się, wciąż dochodzących ludzi. Popiełuszkowie mieli wrażenie, jakby cała Polska zespoliła się w modlitwie za ich syna.

W zeznaniach procesowych tak o tym mówiła: „Na wieść o porwaniu księdza Jerzego władze kościelne i wierni w Polsce podejmowali różne starania, aby go odnaleźć i wyrwać z rąk porywaczy. Wierni natomiast zbierali się w świątyniach i modlili się o powrót księdza Jerzego. Nie wiedzieli bowiem, że już nie żyje".

Jak wynika z zeznań, miała świadomość, co działo się z ks. Jerzym: „O losach syna, księdza Jerzego, po porwaniu wiem od innych ludzi, zwłaszcza od syna Józefa i syna Stanisława. Wiem, że wożono księdza Jerzego w bagażniku samochodu i że był bity, kiedy usiłował się uwolnić. Potem zawieziono go na tamę na Wiśle pod Włocławkiem i wrzucono w nurty rzeki obciążonego kamieniami”.

I dalej: „Ciało mojego syna wydobyto z Wisły w dniu 30 października 1984 roku. Miał związane ręce i nogi, a do nóg miał przywiązane kamienie. Był w sutannie".

O znalezieniu ciała syna, podobnie jak wcześniej o porwaniu, usłyszała wieczorem w telewizji, 30 października 1984 r. Jeszcze tej samej nocy do Okopów udał się z Warszawy cioteczny brat ks. Jerzego, krewny Popiełuszków, ks. Kazimierz Gniedziejko. Z Okopami kontaktu bowiem nie było ze względu na brak telefonów (zostały tam założone dopiero w latach dziewięćdziesiątych XX w.). „Kiedy wszedłem, mama Jerzego siedziała nieruchomo na krześle. Nie płakała, była milcząca, poważna, jakby skamieniała. Oczy na wpół przymknięte. Podszedłem do niej i mocno ją objąłem. Szukałem mądrych, górnolotnych słów pocieszenia, ale nic nie przychodziło mi do głowy. Wyszeptałem w końcu: «W takim razie, ciociu, mamy świętego»" ${ }^{22}$

22 Relacja ustna ks. Kazimierza Gniedziejki, zb. wł. 
Ksiądz Gniedziejko zabrał Popiełuszków do Warszawy. Gdy dojechali przed kościół na Żoliborzu, ujrzeli tłumy. Jeszcze większe niż ostatnio. Weszli do kościoła, w którym akurat kończyła się msza św. Władysław Popiełuszko podszedł do ołtarza i padł na ziemię z dojmującym krzykiem. A matka ks. Jerzego stała przy nim nieruchomo. Ludzie na ten widok zaczęli głośno płakać. Po mszy ktoś zaprowadził rodziców do pokoju ich syna. Nie było jednak z nimi kontaktu, jakby nic do nich w ogóle nie docierało. Jak wynika z relacji Katarzyny Soborak ${ }^{23}$ która do dziś pamięta przenikniętą bezmiarem cierpienia twarz pani Marianny, była ona wówczas jak Pieta.

Następnie Popiełuszkowie musieli się podjąć identyfikacji syna.

Zeznania procesowe: „Zwłoki księdza Jerzego zostały przewiezione do Białegostoku, gdzie w prosektorium Akademii Medycznej przeprowadzono sekcję zwłok. Niektórzy twierdzili, że zwłoki księdza Jerzego z Włocławka były przewiezione do Warszawy, a następnie do Białegostoku. Sekcję przeprowadziła prof. Byrdy. Trudno mi powiedzieć, czy sądowa sekcja zwłok została przeprowadzona w sposób obiektywny. Nie znam się na tym. Słyszałam, że ludzie mieli zastrzeżenia do sposobu przeprowadzenia tej sekcji. Na znak protestu niektórzy ludzie wypisywali na ścianie jej domu brzydkie słowa”.

Te wydarzenia Marianna Popiełuszko także rozpatrywała w kategoriach religijnych. Jak wyjaśniała w prywatnej rozmowie, poczuła wtedy wręcz więź z Maryją, gdyż też cierpiała Ona po śmierci Syna i mimo ogromnego bólu i cierpienia zgodziła się ostatecznie na wolę Bożą, skoro taka musiała ona być. „Prosiłam Matkę Bożą, żebym ja też tak umiała. Pan Bóg najlepiej przecież wie, kiedy kogo zabrać". ${ }^{24}$

Gdy lekarze spisali protokół oględzin ciała, nie chciała go dokładnie czytać. Był zbyt drastyczny. Wiadomo bowiem, że brzmiał on

23 Katarzyna Soborak, notariusz w diecezjalnym etapie procesu beatyfikacyjnego ks. Jerzego, wcześniej uczestniczka Mszy za Ojczyznę, obecnie dyrektor Ośrodka Dokumentacji Życia i Działalności ks. Jerzego Popiełuszki w Warszawie. Szerzej zob. M. K i n d z i u k, Cuda księdza Jerzego. Dlaczego nie wszyscy zostaja uzdrowieni, Kraków 2016.

24 Relacja ustna Marianny Popiełuszko, zb. wł. 
tak: „Zwłoki zawinięte w worek foliowy obwiązany na krzyż, końcówki sznura zawiązane są na węzeł zabezpieczony plombą. Zwłoki ubrane w czarne spodnie zabrudzone ziemią na całej powierzchni, sutanna koloru czarnego podwinięta do pasa. Do obu nóg przywiązany jest worek jutowy, w którym znajdują się kamienie. Przywiązany jest w ten sposób, że białym, plastikowym sznurem skręconym z kilku włókien przywiązany jest do obu nóg w ten sposób, że końcówki sznura wzdłuż pleców biegną do szyi". ${ }^{25}$

Nie była też w stanie dokonać identyfikacji zwłok ks. Jerzego. Jak stwierdziła w zeznaniach: „Przy rozpoznaniu zwłok syna nie byłam. Serce moje by tego nie wytrzymało. Za mnie zrobił to syn Józef oraz przedstawiciele Kurii Metropolitalnej Warszawskiej”.

Zdawała sobie też sprawę, że trudno było ustalić tożsamość zwłok.

Mówiła w zeznaniach procesowych: „Ciało syna było mocno posiniaczone i już trochę zmienione, ponieważ leżało dłuższy czas w wodzie. Przy rozpoznaniu syn Józef odszukał na ciele księdza Jerzego charakterystyczne znamię, a Jacek Lipiński porównał stan uzębienia księdza Jerzego z kartą zdrowia otrzymaną od jego lekarza stomatologa".

Nie dziwi fakt, że mówiła później o sobie: „Ja jestem ból do samego nieba”26. W zeznaniach dodawała: „Księdza Jerzego widziałam w prosektorium, gdy był włożony do trumny i ubrany. Jestem całkowicie pewna, że to był mój syn". ${ }^{27}$

Kiedy natomiast żegnała się z synem w chwili zamykania trumny, klęcząc pocałowała go w nogi i ręce: „Ja niegodna, żebym mogła całować jego twarz" - stwierdziła w zeznaniach.

Wszystko to wskazuje bez wątpienia na ogromne cierpienie matki, która musiała nie tylko przeżyć męczeńską śmierć własnego dziecka, ale też patrzeć na jego zmasakrowane ciało w trumnie i znieść świadomość, że był tak okrutnie bity i torturowany. Musiała też znosić

${ }^{25}$ Protokół z sekcji zwłokks. Jerzego Popiełuszki, b.sygn.; Ośrodek Dokumentacji Życia i Działalności Księdza Jerzego Popiełuszki w Warszawie.

26 Relacja ustna Marianny Popiełuszko, zb. wł.

27 Tamże. 
ataki przedstawicieli komunistycznych władz na ks. Jerzego; nie ustały one bowiem po zamordowaniu kapłana, zwłaszcza, jeśli chodzi o zarzuty wypowiadane przez rzecznika rządu, Jerzego Urbana, który „odegrał szczególnie dużą rolę w kampanii przeciwko ks. Jerzemu Popiełuszce. Pozwalał sobie na formułowanie takich oskarżeń, na które prawdopodobnie nie pozwoliłby sobie nikt inny". ${ }^{28}$

Dalsze zeznania Marianny Popiełuszko pokazują jednak, że patrzyła na wydarzenia z religijnego punktu widzenia. Łączyła je z cierpieniami Chrystusa. Wyrażała pewność, że jej syn poniósł śmierć za wiarę. Po latach natomiast podkreślała słuszność tego sposobu myślenia: „Tam dobrze, gdzie nas nie ma. Zawsze trzeba, żeby było dobrze. Czy dobrze, czy źle - to i tak dobrze. Jak jest, tak jest dobrze. Maryja też była matką. Stała pod krzyżem i cierpiała z Panem Jezusem. Tak i ja zgodziłam się z tym cierpieniem. Widocznie Pan Bóg tak chciał. Co Pan Bóg komu wymianował, to ludzka zazdrość nie ukradnie. A co nie, to i z ręki wypadnie". ${ }^{29}$

Jej sposób myślenia był jasny, prosty, logiczny, a zarazem twardy i realistyczny. To, co się wydarzyło, stanowiło też dla niej prostą konsekwencję wyboru drogi życiowej przez ks. Jerzego: „Skoro poszedł na księdza, to musiał wiedzieć, że może zostać męczennikiem. Bo oddanie życia za wiarę jest wpisane w powołanie kapłańskie". ${ }^{30}$

\section{To wyraz nienawiści do wiary}

Marianna Popiełuszko musiała znać zarzuty, jakie padały pod adresem jej syna, na temat politycznego charakteru jego działalności. Przysłuchiwała się procesowi zabójców ks. Jerzego, jaki się toczył w Toruniu na przełomie 1984 i 1985 r. i który w końcowym

28 J. O 1 a s z e k, Antysolidarnościowa propaganda władz PRL, w: Ł. K a m i ń s k i, G. Wa li g ó r a (red.), NSZZ Solidarność 1980-1989, t. 7, Instytut Pamięci Narodowej. Komisja Ścigania Zbrodni przeciwko Narodowi Polskiemu, Warszawa 2010, s. 172.

29 Relacja ustna Marianny Popiełuszko, zb. wł.

30 Tamże. 
akcie oskarżenia zawierał stwierdzenie o „szkodliwej dla interesów państwa pozareligijnej działalności" ks. Popiełuszki. ${ }^{31}$ Ona miała jasne przekonanie, że zabicie jej syna nie było zwykłą zbrodnią, ale aktem walki z Kościołem.

W zeznaniach tłumaczyła: „Moim zdaniem, śmierć księdza Jerzego to nie przejaw zwykłej zbrodniczej działalności, ale wyraz nienawiści do wiary i do Kościoła. Syn Jerzy był tylko ofiarą tej nienawiści. Mordercy i ich zleceniodawcy uważali, że zabijając mojego syna, wyrządzą krzywdę Kościołowi i zniechęcą go do troski o wiernych".

Dodała: „Moim zdaniem, władze bezpieczeństwa dokuczały synowi, księdzu Jerzemu, ponieważ uważały, że jak przestraszą jednego znanego kapłana, to i inni będą się bali. Jest to przykład walki z Kościołem. W Piśmie Świętym wyczytałam, że jak się uderzy w pasterza, to rozproszą się owce".

Marianna Popiełuszko nie znała kościelnych dokumentów opisujących koncepcję męczeństwa ${ }^{32}$ ani watykańskich instrukcji na ten temat, jak choćby Instrukcji Kongregacji Spraw Kanonizacyjnych,

31 Zob. E. W e n d e, Sprawa ks. Jerzego Popietuszki. Mechanizm i retoryka zbrodni. Kościót i społeczeństwo wobec stanu wojennego, Warszawa 2004.

32 Najdokładniejszy dotąd opis kryteriów i procedur kanonizacyjnych pozostawił papież Benedykt XIV (sporządził go, gdy jeszcze jako kard. P.L. Lambertini pracował w rzymskich kongregacjach), w księdze III swego ogromnego dzieła $O$ beatyfikacji Stug Bożych i kanonizacji błogosławionych wydanego w Bolonii w 1738 r., które było podstawą do przeprowadzania procesów beatyfikacyjnych i kanonizacyjnych do czasów II Soboru Watykańskiego. Jak uczył papież, świadectwo wiary istnieje nie tylko wtedy, gdy znosi się cierpienie dla osoby Chrystusa i Jego nauki, ale także, gdy cierpi się z powodu wyświadczanego dobra, ze względu na unikanie grzechu albo z racji na jakiekolwiek dzieło sprawiedliwości, czynione z miłości do Chrystusa. Cierpiąc za takie wartości, jak prawda, sprawiedliwość czy miłość, wyznawanych w imię Chrystusa, znosimy cierpienie dla Tego, który jest Prawdą, Miłością itd.; zob. J. N a u m o w i c z, Ks. Jerzy Popiełuszko - klasyczny męczennik, w: M. K i n d z i u k (red.), Śmierć bt. ks. Jerzego Popietuszki z perspektywy 30 lat, Wydawnictwo UKSW, Warszawa 2016. 
pt. Sanctorum Mater, wydanej w 2007 r. ${ }^{33}$ Intuicyjnie jednak wyczuwała i była do tego przekonana, że w stwierdzeniu męczeństwa ważne jest także określenie motywów działania prześladowcy, które określa się tradycyjnym wyrażeniem „nienawiść do wiary”. A jest to jeden z istotnych elementów „uznania męczeństwa przez Kościół”. ${ }^{34}$ $\mathrm{Z}$ uwagi na to, że męczeństwo ks. Jerzego jego matka traktowała w kategoriach klasycznego rozumienia męczeństwa w Kościele, ${ }^{35}$ i wskazywała, że śmierć jej syna nastąpiła w wyniku prześladowań za wiarę, nie mogło być i nie było w jej sercu miejsca na nienawiść do oprawców. To logiczna konsekwencja takiego sposobu myślenia.

Mówiła bowiem: „Mordercy nie z synem, tylko z Bogiem walczyli. Przecież oni uderzyli nie w Popiełuszkę, ale w sutannę. Uderzyli w cały Kościół. Ale nikogo nie osądzam, śmierci niczyjej nie żądam. Pan Bóg sam kiedyś osądzi. Ile trzeba, tyle mordercy będą musieli odpokutować. Niech im Pan Jezus daruje. Najbardziej bym się cieszyła, żeby się oni nawrócili. Ja już im przebaczyłam".

Świadectwo Marianny Popiełuszko nierozerwalnie zatem wiąże się również z przebaczeniem, które ustępuje miejsca nienawiści czy chęci zemsty, przez co znakomicie odpowiada pojmowaniu męczeństwa w tradycji Kościoła. W chrześcijańskim męczeństwie bowiem bardzo ważny pozostaje element przebaczenia. Motyw ten poruszał zresztą abp Angelo Amato podczas beatyfikacji ks. Jerzego w 2010 r. W swej homilii podkreślał, że ,ks. Popiełuszko nie wykazywał wrogości wobec swoich przeciwników. W jego działaniu nie widać było antypatii w stosunku do osób czy nienawiści w odniesieniu do oprawców. W kazaniach wzywał do zgody. Jego dewizą stały się słowa św. Pawła: Zło dobrem zwyciężaj”. ${ }^{36}$ Zresztą, w każdej Mszy za Ojczyznę w modlitwie powszechnej prosił o wyzwolenie z nienawiści

33 Por. H. M i s z t a 1, Sanctorum Mater: instrukcja Kongregacji Spraw Kanonizacyjnych o prowadzeniu dochodzenia diecezjalnego lub eparchialnego w sprawach kanonizacyjnych: komentarz.

34 B e n e d y k t XVI, Przemówienie do sesji plenarnej Kongregacji Spraw Świętych, 24 IV 2006 r., Acta Apostolicae Sedis 98(2006) nr 5, s. 399-400.

35 Szerzej zob. J. N a u m o w i c z, Ks. Jerzy Popiełuszko - klasyczny męczennik.

36 Pełny tekst homilii zob. L'Osservatore Romano, wyd. pol. 7/2010, s. 58-60. 
i o zwycięstwo prawdy. ${ }^{37}$ Ta atmosfera przebaczenia panowała także po śmierci męczennika. Prymas Józef Glemp w homilii wygłoszonej podczas jego pogrzebu 3 listopada 1984 r. mówił: „Odpuszczamy zabójcom księdza Popiełuszki. Nie mamy do nikogo nienawiści”. ${ }^{38}$

W tym dokładnie duchu mówiła w zeznaniach Marianna Popiełuszko.

\section{Mój syn jest męczennikiem w sensie religijnym}

Marianna Popiełuszko w zeznaniach odnosiła się również do kultu ks. Jerzego, którego spontaniczny rozwój obserwowała od chwili męczeńskiej śmierci syna. „Mój syn Jerzy od chwili śmierci cieszy się sławą męczennika za wiarę, za krzyż i miłość Ojczyzny. Niektórzy może odwiedzają jego grób z ciekawości i znają syna z pracy wśród robotników, ale on zginął w obronie wiary i Kościoła w Polsce".

Tłumaczyła, że kult ten był oddolny i spontaniczny: „Kiedy przyjeżdżam do grobu księdza Jerzego, a czyniłam to początkowo co miesiąc, zawsze widzę przy grobie bardzo dużo kwiatów, zniczy i lampek. Jako matkę mnie to bardzo wzrusza i nie widzę w tym nic złego, ponieważ w Polsce na wszystkich cmentarzach i na wszystkich grobach ludzie składają wiązanki kwiatów i palą znicze. Jest to wyraz naszej pamięci o zmarłym. O księdzu Jerzym pamięta cała Polska, i nie tylko, i w dowód pamięci składa kwiaty. Podobnie się dzieje przy jego pomnikach, bo już takie ma wystawione, i na symbolicznych grobach, na przykład w Suchowoli. Byłam przy odsłonięciu pomników księdza Jerzego: w Białymstoku, Jarosławiu, Gdańsku, Suwałkach, Piotrkowie Trybunalskim i w Paryżu”.

Tylko przez pierwsze dwa tygodnie grudnia 1984 r. do grobu przybyło w zorganizowanych grupach ponad 12 tys. osób z całej Polski. Do 2017 r. przybyło ponad 20 mln osób z całego świata. Sama Marianna Popiełuszko zaczęła spotykać się przy grobie ks. Jerzego z wielkimi tego świata. Najpierw - w grudniu 1984 r. - z premierem Włoch, Giulio

\footnotetext{
37 M. K i n d z i u k, Świadek prawdy, s. 240.

38 J. G 1 e m p, Homilia na pogrzebie ks. Jerzego Popiełuszki, w: tamże, s. 172-173.
} 
Andreottim. Później modliła się tu w obecności wiceprezydenta Stanów Zjednoczonych, George'a Busha (zachowało się zdjęcie, na którym Bush obejmuje ją ramieniem), prezydenta Czechosłowacji, Václava Havla. Rozmawiała z prezydentem Rumunii, Emilem Constantinescu, z Margaret Thatcher, premier Wielkiej Brytanii. Na bieżąco śledziła długą listę: był książę Luksemburga Jan Wielki, prezydent Bułgarii Żeliu Żelew, premier Węgier Victor Orban, Zbigniew Brzeziński, prezydent Ryszard Kaczorowski. A także prymasi i kardynałowie z wielu krajów: Anglii, Austrii, Białorusi, Brazylii, Czech, Chile, Filipin, Meksyku, Niemiec, Rwandy, USA oraz kardynałowie i arcybiskupi z Watykanu - przewodniczący różnych kongregacji i komisji papieskich. Wśród dostojnych gości byli też m.in.: prymas Anglii kard. George B. Hume, prymas Filipin Yaime Sin, prymas Meksyku abp Ernesto Couripio Ahumada, prymas Czech kard. Miroslav Vlk, kard. Karl Lehmann.

Datą, którą na zawsze zapamiętała, był 14 czerwca 1987 r. To właśnie wtedy do grobu ks. Jerzego przybył papież-Polak Jan Paweł II. „Ja jako matka jestem przekonana, że mój syn ksiądz Jerzy jest męczennikiem w sensie religijnym, to jest męczennikiem, który bronił krzyża, wiary i Ojczyzny". Marianna Popiełuszko widziała pracę i śmierć swego syna wyłącznie w sensie religijnym. Miała też świadomość, że zetknął się on z wrogim systemem. Mówił o tym abp. A. Amato podczas mszy beatyfikacyjnej w Warszawie: „Wrogość tego systemu wobec ludzi wierzących przejawiła się w wielu wydarzeniach z życia ks. Popiełuszki. Zwłaszcza w ostatnich latach życia doznawał nękań ze strony tajnych służb: ten bezbronny kapłan był śledzony, prześladowany, aresztowany, torturowany a ostatecznie brutalnie związany i, choć jeszcze żył, został wrzucony do wody. Jego oprawcy, którzy nie mieli najmniejszego szacunku dla życia, z pogardą odnosili się nawet do śmierci. Porzucili go, jak niektórzy porzucają martwe zwierzę"39.

W uznaniu męczeństwa są bowiem brane pod uwagę nie tylko wielość zadanych udręk i poniesionych prześladowań, ale powód ich

39 A. A m a t o, Homilia. Beatyfikacja ks. Jerzego Popiełuszki 6 VI 2010, s. 58-60. 
dokonania (martyrem non facit poena sed causa - głosi znana zasada stosowana w tym przypadku). ${ }^{40}$ Chodzi o motywację męczennika, dlaczego przyjmuje cierpienie, ale także racje, jakimi kierują się prześladowcy. Racje prześladowców są określane ogólnie jako nienawiść do wiary i do wartości, jakie z wiary wypływają i z wiarą się wiążą, takie jak miłość, głoszenie prawdy, obrona zasad etycznych itd. Natomiast ze strony męczennika, znoszenie tortur i śmierć są jedynie potwierdzeniem wierności Bogu aż do końca.

Matka ks. Jerzego, jak wynika z jej zeznań, była przekonana, że tak niezłomna wiara jej syna wypływały z mocy, którą otrzymał on od Boga. To Jemu ks. Jerzy zaufał bezgranicznie, On więc dał mu siłę wytrwania w męczeństwie i uczynił go świętym. Dlatego też mogła wypowiedzieć w zeznaniach znamienne słowa: „Mam nadzieję, że Pan Bóg przyjął go do nieba i że się kiedyś z nim spotkam”.

\section{A teraz to już radosne}

Trzeba też podkreślić, że Marianna Popiełuszko uczestniczyła także w zakończeniu diecezjalnego etapu procesu beatyfikacyjnego ks. Jerzego Popiełuszki. Miało to miejsce 8 lutego 2001 r. w kościele św. Stanisława Kostki w Warszawie. Podczas specjalnej sesji postulator tego procesu, ks. Zdzisław Król, wyraził nadzieję, że Kościół po zbadaniu zebranych przez Trybunał materiałów dowodowych uzna, iż ks. Popiełuszko był człowiekiem wiary i miłości, który za wierność tym wartościom oddał życie. Promotor sprawiedliwości, o. Gabriel Bartoszewski, zapewnił prymasa Polski, że w przeprowadzeniu postępowania nie było żadnych uchybień w procedurze. Wtedy notariusze przekazali kard. Glempowi liczące 900 stron akta procesu, które zostały następnie zawiezione do watykańskiej Kongregacji Spraw Kanonizacyjnych. ${ }^{41}$

40 Zob. W. Ł a z e w s k i, La sentenza agostiniana ,,martyrem non facit poena sed causa”, Pontificia Universitas Lateranensis, Roma 1987.

${ }^{41}$ Szerzej zob. M. K i n d z i u k, Matka świętego, Kraków 2012. 
„Wtedy zrozumiałam, że on już za życia był święty” - przyznała Marianna Popiełuszko. ${ }^{42}$ Pokazuje to, że jej wizja męczeństwa obraca się wokół całego życia syna, nie ogranicza się natomiast tylko ostatniego momentu przed śmiercią i do samej śmierci.

Proces diecezjalny zakończył się w 2001 r. Wszystkie akta procesu przetłumaczone na język łaciński trafiły wtedy do watykańskiej Kongregacji ds. Świętych. Męczeństwo ks. Jerzego Popiełuszki ostatecznie uznał i potwierdził papież Benedykt XVI, który 19 grudnia 2009 r. stwierdził: „W sprawie Sługi Bożego Jerzego Popiełuszki, kapłana diecezjalnego, istnieje pewność co do męczeństwa i jego przyczyny oraz co do rozpatrywanych skutków [beatyfikacyjnych]". 43 To była podstawa do wyniesienia duchownego na ołtarze.

Marianna Popiełuszko uczestniczyła również w uroczystej beatyfikacji swego syna w czerwcu 2010 r. na placu Piłsudskiego w Warszawie, a do ołtarza, przy którym abp. Angelo Amato miał odprawiać wówczas mszę św. beatyfikacyjną, niosła w procesji relikwie swego syna. Słowa, które wtedy wypowiedziała także świadczą o jej głębokim rozumieniu męczeństwa: „Kiedy księdza Jerzego porwali i zabili, to było straszne. A teraz to już radosne! Trzeba zrozumieć, po co relikwie są potrzebne". ${ }^{44}$

Trzy lata po beatyfikacji, w 2013 r., Marianna Popiełuszko zmarła. Miała 93 lata.

Milena KINDZIUK

42 Relacja ustna Marianny Popiełuszko, zb. wł.

43 Ogłoszony 19 XII 2009 r. dekret O męczeństwie (Super martyrio) ks. Popiełuszki podaje, że papież Benedykt XVI przyjął i zaaprobował propozycje Kongregacji Spraw Świętych i „dzisiaj ogłosił”: Constare de martyrio eiusque causa Servi Dei Georgii Popietuszko, Sacerdotis Dioecesani, in casu et ad effectum de quo agitur. Pełny tekst tego dekretu opublikował urzędowy organ promulgacyjny Stolicy Apostolskiej: Acta Apostolicae Sedis 52 (2010) nr 10, s. 666-668, tu: s. 668.

44 Relacja ustna Marianny Popiełuszko, zb. wł. 
Słowa kluczowe: ks. Jerzy Popiełuszko, Marianna Popiełuszko, męczeństwo, zeznania w procesie beatyfikacyjnym, męczennik za wiarę

Keywords: ks. Jerzy Popieluszko, Marianna Popieluszko, martyrdom, testimony in the beatification process, a martyr for the faith

\section{The Vision of Martyrdom in the Testimonies of Marianna Popieluszko in Fr. Popiełuszko's Beatification Process}

\section{Summary}

In the history of the Church one finds an event wherein a mother was questioned in the beatification process of her son. This occurred in the case of Marianna Popiełuszko, who before the court of beatification in Warsaw in 1997, responded to all the questions put to her in order to assess the life and work of Fr. Jerzy Popiełuszko as a candidate for sainthood by Church authorities.

From these testimonies there emerges an interesting picture of the life and death of Fr. Popiełuszko, as well as his faith and steadfastness. It helps to read the true intentions which were of a religious nature that guided him during his activity. Moreover, this confirms the martyrological nature of his death, in which what counts is not only the anguish inflicted, but the reason for one's achievements. This also demonstrates that martyrdom was the crowning achievement of his life of faith and love, which was associated with forgiveness that is opposed to hatred or vengeance.

This vision of martyrdom is consistent with the classical understanding of martyrdom in the Church, which is not limited only to the moment of death, but applies to the entire life of the martyr. 